\title{
Approaches to the Narrative Itinerary of José Martí
}

\author{
Mauricio Núñez-Rodríguez \\ Ph.D. in Literary Sciencies \\ Researcher \\ Centro de Estudios Martianos \\ Cuba \\ Received: 4/08/2018 \\ Accepted: 18/11/2018 \\ DOI: https: //doi.org/10.15359/tdna.35-65.6
}

\section{Abstract}

This essay approaches the side of José Martí as narrator, which has remained in the periphery of the critics' interest due to the poetic, journalistic and revolutionary work of the author. It delves into a group of pieces that constitute a narrative system itself in his literary work not following the traditional canon.

Keywords: José Martí, narrative system, chronicle, journalism, Latin American Literature

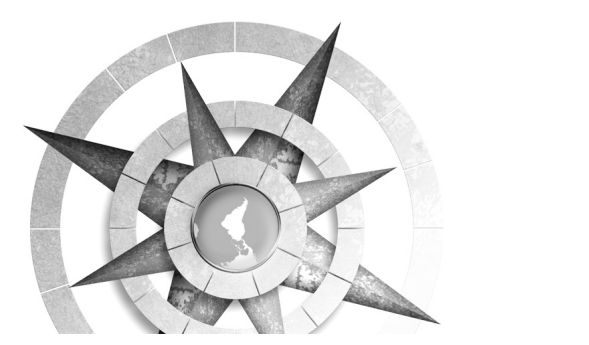

Este ensayo constituye un acercamiento a la faceta de narrador de José Martí la cual ha quedado en la periferia de interés de la crítica ante la obra poética, periodística y revolucionaria del autor. Es una indagación que se detiene en un grupo de piezas que constituyen un sistema narrativo en su obra literaria que no se atiene a los cánones tradicionales.

Palabras clave: José Martí, sistema narrativo, crónica, periodismo, literatura latinoamericana

\section{Resumo}

Este ensaio é uma abordagem à faceta de José Martí como narrador. Esta faceta ficou na periferia do interesse do crítico pela obra poética, jornalística e revolucionária do autor. 
Trata-se de uma investigação que se detém num conjunto de peças que constituem um sistema narrativo na sua obra literária que não respeita os cânones tradicionais.

Palavras chave: José Martí, sistema narrativo, crônica, jornalismo, literatura latino-americana

By following the thesis of the Israeli theorist Itamar Even-Zohar, a narrative system can be established in the literary creation of José Martí that has not been evaluated in the same dimension as other facets of his work, but which shows its first expressions in some of his juvenile texts written during his stay in Spain: Castillo and El presidio politico en Cuba (1871), the story Hora de lluvia (1873), the two versions of the drama Adultera (1872-1874) and concludes in his Campaign diaries (1895).

The Martian narrative system -whose nature does not always conform to traditional or canonical genres- is an indissoluble part of his poetics, both from a stylistic and conceptual point of view, and its peculiarities become more complex parallel to his intellectual maturity.

The most distinctive works of this narrative system emerge in the stage of greater stability and poetic creation of the poet during the years he lives in the United States, approximately between 1880 and 1895. To this period corresponds the story Irma (1884), it is known Amistad funesta (1885), his translations of novels (Mystery, 1886 and Ramona, 1888); the translation of the story Mes fils by Victor Hugo is published in 1875 in the Revista Universal de México.

Also, his narrative system is integrated by the stories of the four issues of the magazine La Edad de Oro (1889), and his work as a chronicler. To this collection should be added his travel journals in Mexico, Guatemala and Venezuela, and the fragments of novels and stories in the notebooks as well as the narrative nature of his poetry. The "Tale of war. Lieutenant Crespo" (1991: pp. 365-370) published in the Patria newspaper in 1892 also articulates this system ${ }^{1}$.

In an exhaustive plot of the narrative itinerary of the author, one should take into account the stories and fragments belonging to different stages of his life -which are almost never noticed-scattered in his notebooks compiled by Ángel Esteban in the volume José Martí: Complete stories.

1 José Martí "Cuento de la guerra. El teniente Crespo" . This piece offers the combative feats of Jesús Crespo, a soldier of the Cuban independence army. The author prints the same rhythm of combat: the incessant movement of the riders, the machetes, the rifles, the shots that come and go. It is a story in the middle of the battlefield that is characterized by brief sentences, nouns adjectivalized with precision and objectivity, subordination and syntactic chaining are avoided. The expression is fluid, clear and direct without digressions in the action. 


\section{The Golden Age and other Stories.}

As for the stories and fragments from the notebooks we have found seventeen, almost all of a few lines. In the notebook no. 2, from the Spanish era (1871-1874), there are eight fables of fools, very short, with some moral or didactic content. [...] in the notebook no. 9 , of 1882 , we have found two fables [...]. Finally, in the notebook no. 18 , of 1884 , is the most original story -apart from those of La Edad de Oro, better elaborated and of greater expressive strength of Martí, that we have titled "Cuchillo de plata fina" and another one, titled "The drama" (Esteban, 1995: XLI)

But this is an investigation to be done. When defining the narrative background in the author's work, we must take into account, above all, his juvenile texts, those that belong to his Spanish period. The story "Hora de lluvia" can be placed in this consideration. The note that precedes it is dated April 29 ${ }^{\text {th }}, 1873$ and is addressed to Blanca de Montalvo, Martí's girlfriend in Zaragoza. It was published without a signature on the no.17 of the Universal Magazine of Mexico, in October of 1875.

The text constitutes a self-portrait of his mood at that time. In the dialogue between the two characters emerge his anguish, his cravings, and his desires. "The country has stolen my youth for itself"2, says the narrator, probably referring to the stage in which he was in prison and the resulting physical and psychological traces.

The narrative is divided into seven sections. It is a piece that, supposedly, is written in an hour and its discourse is glossed by a temporary and, at the same time, structuring element: "at half past eight", "it is nine o'clock", "it is nine and ten ", "it's nine and twenty-five minutes." The argument of the story is continuity of his constant concern for the surrender to the homeland. It is a motive that is reiterated. An idea expressed in other pieces corresponding to this stage.

It is frequent to affirm that Amistad funesta or Lucía Jerez is the only piece written by José Martí in the novelistic genre. His Spanish version of the novel Ramona by Helen Hunt Jackson -despite the well-known style of José Martí when doing this task-I consider it a translation. According to the critic, Martí used to enrich the discourse with his personal stock; but, in this case, the author relies on a starting text-which constitutes the volume of the North American writerSee El traductor Martí, by Lourdes Arencibia (2000) or the flag work: "Ramona: a new movement of prolonged fiction" by Maia Barreda.

2 See Martí, J. "Hora de lluvia", in Anuario del Centro de Estudios Martianos, no. 4, La Habana, 1981, p. 8 
It is true that there are multiple affinities between the translator and the selected work; hence a close empathy is generated. No other novel leaves such a high impression on him. On this occasion, a full identification is established between José Martí and the work, the author, the characters, the recreated matter, the dramatic situations and the space where the action takes place: Baja California, a territory of Mexico (a very expensive Latin American country to the author).

The Martian praises to this novel are very eloquent. It is one of the pieces with which he establishes a dialogue sustained from his creative work: "this novel, truly remarkable", "Helen Hunt Jackson, [...], has written perhaps in Ramona our novel", "that charming novel of the Californian life ", health and piety infuse in the spirit those artistic and ardent pages". When Martí refers to "our novel" he expresses a sense of belonging as a critic, translator and also as a Latin American. To any other piece of the ones reviewed in his chronicles he showed such complicity.

José Martí translates Ramona at times when the piece already had a trajectory in the United States in its original language. First, it appeared serially in the weekly The Outlook in 1884, and then in the form of a book in 1885 . He decided to present the Hispanic American reader with a successful text. The first edition of his translation is from 1888 . I consider him a translator with a peculiar style because there is a starting text with a previous trajectory. Thus, his translation of Ramona is known in the year 1888 , that is, after the writing and publication of Amistad funesta (1885). I think it more accurate to consider this translation more as part of his narrative itinerary after his novel than as part of his narrative background.

José Marti's translating activity underlies in much of his literary work, both in prose and verse ${ }^{3}$ and is part of his great effort to keep the Spanish-American people informed of events, not only cultural, but also political, economic, scientific and technological of the United States.

According to the Chronology of Doctor Ibrahim Hidalgo Paz (2012) Martí concludes the "Prologue" for the edition -which was already in print- in September 1887. Possibly, his translation work corresponds to the first semester, that is, always after the writing and publication of his novel. Ramona's impression ends in July 1888.

The dramatic creation of José Martí also served as a reference at the time of the writing of his only novel. The drama also rests in a conflict, which must have an introduction, a development

3 See: Carmen Suárez León: "Martí: traductor de textos, traductor de mundos", in Anuario del Centro de Estudios Martianos, no. 25, La Habana, 2002, p. 178. 
and conclusions in an evolutionary and gradual way, divided into acts and these, in turn, in scenes. Possibly, his training in the construction of characters was useful to the author, characterizing them psychologically and plotting the complexities of each one throughout the action.

Creating credible and organic dramatic situations was the strategy that served him in the seven hurried days in which he wrote his novel, the characters and the complexities of his psychological characterizations.

If we start from the sine qua non condition that for a story to exist there must be a conflict and for a drama to exist there must be a conflictive situation, then José Martí was nourished by his previous experience as dramatist and of those dramatic structures. The intrigue that is woven throughout the action in Adultera before the eyes of the reader, which forces one to wonder if one of the characters will surprise his wife with the lover, is reiterated years later in his novel, with the fate of the uncontrolled jealousy of the protagonist. All his dramatic work precedes the writing of his novel. Each of his pieces could be considered antecedents to a greater or lesser extent of the speech of it. There is a need within the author to observe and artistically recreate the deep complexities of the human soul. His creative talent is provided using all the resources available.
The two versions of Adultera correspond to the author's stay in Spain (1872-1874). They are texts of youth. The marks of the erotic discourse that concentrates the attention of critics about her novel in the period 2003. 2013 could have its antecedent in the dialogues and parliaments of Adúltera. There are similarities in the tragic end of both stories: while in adultery the cheated spouse eliminates the subject of infidelity (the lover of his wife), in the novel, the protagonist decides to end - dramatically and brutally - the life of the character for whom his love for Juan Jerez feels threatened. Likewise, the sensuality that characterizes the discourse of Amor con amor se paga (Mexico, 1876) appears again in Lucía Jerez. Even from a piece as early as Abdala (1869), the author draws a feminine psychology in conflict. Beyond the firm decision of the protagonist to fulfill the duties with the mother country, what greater dilemma for a mother that to see leave one of her children for a war?

There are areas of his dramatic work that converge in the discourse of the novel. In a study already published, (Núñez, 2002) I establish the communicating vessels that are established between Patria y libertad (Drama indio), written during his stay in Guatemala, the Guatemala essay and the speech of his novel. The author's dramatic work, as a corpus - in its narrative-dialogical condition - can integrate 
the antecedents, not only narratives, in its creation in relation to the novel.

In the year 2000 in the workshop "Lucía Jerez: desafío al tiempo" -about the 115 years from the publication of the workCintio Vitier and Fina García Marruz offered the initial interventions. García Marruz expressed that among the many readings the piece inspired her - in addition to what was already expressed in his study published several times - was to imagine it as a theatrical performance, since each of the scenes were drawn as if they were to be delivered to a director for his staging. That reading, she said, had been troubling her for many years and as a result of that she had written, decades ago, a script for ballet, but for shyness she never showed it to any specialist, let alone the National Ballet. Through the efforts of the institution, the text came into the hands of Alicia Alonso. Subsequently, the ballet was known from the idea of García Marruz.

And it is true; there are numerous scenes in the speech of Lucia Jerez that seem to have been elaborated to be represented: the concert of the pianist Keleffy, for example, or the interpretation of Sol del Valle, both in the third chapter. But there are two fully dramatic scenes: the inner monologue of Lucía Jerez in her room, which allows to know the extent of the fierceness of her nature and that is the prelude to the final scene where she expresses the debauchery of her jealousy when she takes one of the adornment pistols in the country ranch and shoots Sol del Valle.

Unlike other novels in which the protagonist dies, suffers or asks another character to carry out his revenge ${ }^{4}$, in this narration the protagonist is the one who executes, with his own hands, the tragic decision to eliminate the character that makes her vulnerable. This unusual ending, in a way, distances it from the sensitivity of the 19th century.

The intense and heterogeneous journalistic creation of the poet in the United States in the approximately fifteen years that he lived there is known. This work precedes, accompanies and maintains, after the writing and publication of his novel, but they are not texts of youth, but correspond to the period of greater maturity, stability and intellectual creation of José Martí. In the drawing of a narrative itinerary in his literary work - both before and after Lucia Jerez - his work as a chronicler occupies a significant place.

4 In the last scene of the novel Cecilia Valdés by Cirilo Villaverde, the protagonist talks with José Dolores Pimienta and tells her that the marriage between Leonardo and Isabel cannot be consummated. This quickly goes to the Church of the Holy Guardian Angel and, at that moment, she says: "Not him. To her". In the film version of Humberto Solás while Pimienta runs through the streets of Old Havana, he recalls Cecilia's recent words echoing: "Not him. To her". 
Numerous of his Spanish and North American scenes show a narrative seed. In the chronicle that he writes on December $24^{\text {th }}, 1881$, addressed to La Opinión Nacional entitled "Puertos and porteños”, (Martí, 1991) he begins by presenting the reader the city of Santander in an integral way: its people, its architecture, its sources of employment, nature; then he does it with Valladolid, before concentrating on the news events that interest him in those regions. In another, from April 15 ${ }^{\text {th }}$, 1882, "Cataluña contra España” [Cataluña against Spain], (1991) he fluently threads three news nuclei of different nature: protests in Barcelona for the signing of a commercial treaty between France and Spain, the presence of Sarah Bernhardt in a theater in Madrid and the death of the bullfighter Ángel Pastor. Three events incoherent with each other as part of the same narrative about Spanish life of the time. His tempo is agile, without digressions or extensive descriptions or unnecessary details. It is a chronicle very well structured with a moving end for the agony of the young bullfighter after being rammed by a bull in the Plaza de Madrid.

The volume on the North American Scenes prepared by the department of the critical edition of the Centro de Estudios Martianos, Ediciones de Archivo de Francia [Center of Martian Studies for the Archive Editions of France (Rodríguez y Fernández Retamar, 2003), coordinated by the doctors Roberto Fernández Retamar and Pedro Pablo Rodríguez, published in 2003, gathers more than three hundred pieces. From the reading, collation and analysis of the information as part of the team that prepared it later emerged the José Martí essay: narrar desde el periodismo (Núñez, 2014). The study focuses on the evolution of the narrative attitude in two sets of Martian chronicles of different nature: one of political profile (those dedicated to the Cutting case) and those texts from which the poet welcomes three of the structures that symbolize modernity in the United States (the chronicle about the inauguration of the Statue of Liberty, the ones dedicated to the Brooklyn Bridge and the one referred to Coney Island).

Any of these chronicles could be read from its narrative nature. In one of those dedicated to the Brooklyn Bridge ${ }^{5}$ for example, it offers details of each of the stages of its construction process, the dimensions and characteristics of all its metal structures, as well as the multiple complexities and obstacles faced by the specialists and builders from the first works, but also stops in the biography of the two engineers (father and son) that made it possible and the role played by the wife and mother for the completion of the complex work.

5 See: José Martí: Obras Completas. Edición crítica, t. 18, Centro de Estudios Martianos, La Habana, 2011, pp. 32-42. (In Spanish) 
This quality of the chronicle is what allows more than one scholar to agree with the idea of tracing a fictionalized story of the United States through the American Scenes, at least at the stage in which its author remained there. It is not by chance that the author himself calls his chronicles "scenes" in the letter to Gonzalo de Quesada y Aróstegui before leaving for the war in Cuba in 1895, a document considered his literary testament and where he gives this section great value. (OC, v. 20, p. 479).

In Lucía Jerez's speech, the poet, the journalist, the critic, the narrator, the translator, the dramatist and the keen observer and analyst are intertwined. Hence the generic confluence in his pages, which go through the narrative, journalism, essay, drama, always with a deep lyricism. Numerous Martian texts cannot be analyzed according to the canonical or traditional genres, but the discursive symbiosis is what predominates. In the case of his novel, there are many voices that converge in his speech: it is a singular text. The text of the Martian novel dialogues with the author's own previous creation and, in turn, not only with the legacy of other architects who precede him, but also with those who are contemporary. The presence of the novels Maria (1867), of the Colombian Jorge Isaacs, and Amalia (1851), of the Argentinean José Mármol, constitute the continuity of that communication now from the text itself.
It is no coincidence that two characters are enjoying reading as an expression of the preferences of that moment: "Pedro, for other women so feared, was with the greatest tranquility set by Sol, and to be read the Amalia by Mármol or the Maria by Jorge Isaacs." (OC, v. 18 , p. 262).

I have always wondered if the presence of both titles would be, in addition, a sign-that subliminally- presages the tragic end of the piece, from the unfortunate outcome of those stories, if we consider the style in which the nature traits of each character have been presented through the image of the cups they use or the flowers they prefer. That detail adds to the narrator's marked intention to suggest more than say.

But his presence confirms, not only the author's knowledge about the novel creation of the time, but also his preference for these romantic pieces and their authors shown in other occasions in his work.

The love story between Efraín and María is only mentioned again from La Nación on the subject of an English version: "Boston reads a lot of Spanish and applauds Maria's English version by Isaacs." (OC, v. 6, p. 78). Everything seems to indicate that the interest in Amalia was superior. In 1887 from the pages of The Liberal Party on the subject of a reference to its author he said: "Marmol, that of the epic Amalia" (OC, 
v. 7, p. 352) and the attention would continue in the future, if we are guided by his collection of Fragments: "Russian women remember Amalia by Marmol: how? --because human beings from here and from there live under the same tyranny: Russia; Rosas." (OC, t. 22, p. $65)$. On the death of the Argentine author it seems that Martí had planned to prepare some semblance in the style of those dedicated to personalities (and other characters) from his North American Scenes. One of its multiple fragments confirms this:

Oh! Undoubtedly: with Marble something of the American heart left the earth. -With each great poet, something of one's own heart leaves the earth.

- What matter of love, of pain, of country has not moved the strings of his lyre? or what brush copied with more delicacy the spirit to the tender and energetic pair, soul of eagles in body of gazelles, of the gentile bonaerenses? His novel Amalia has all the somber color of its time. It was written by a great poet with the pen of a great historian. (OC, v. 22, p. 165)

The tragic love story between Amalia Sáenz and Eduardo Belgrano is framed during the stage of Juan Manuel de Rosas in Argentina (1832-1852), specifically in the period between May $4^{\text {th }}$ and
October $5^{\text {th }}, 1840$, months in which there is a bitter persecution against his opponents (The Unitarians). This year has transcended in history as the year of terror.

José Marti's dialogue with this piece by José Mármol and with the romantic novelistic creation could possibly continue - if that fateful May $19^{\text {th }}$ had not occurred - not only as a narrator and journalist but also as a critic. This is shown by other notes from his Fragments where he mentions a brief list of novels that he could possibly study or at least was interested in:

La novela en América
Manuela
Enriquillo
María Julia?
Amalia
Martín Rivas
La Novia del Hereje
Los Amores de Marta
Brenda (?)
La de Milla.
Francisco, -Cecilia Valdés.
de Meza-El Capitán L. de la Cruz.
(v. 22, pp. 227-228)

While these characters were enjoying the reading of two of the creations that were subsequently legitimized as the most representative of romanticism in Latin America, which denotes the author's fine sensitivity and critical acuity, that presence in the aforementioned 
fragment is part of the narrator's interest in showing the most recent, the most innovative of the society around the artistic, musical and literary creation of the time, characteristic of the modernist narrative.

Romanticism and modernism are not opposed aesthetics. The second is the result of the adaptation of the first to the new times. These are the changes imposed by the complexity of a more modern society. The speech of the novel has traits that relate it to the romantic stage and, in turn, others link it to the new era that was brewing in the writings of the continent in those years and of which the author was a precursor.

The main conflict of the work, in the first instance, is the tragic love story between two characters: Juan Jerez and his cousin Lucía Jerez. Happiness that is truncated by the arrival on the scene of a third party: Sol del Valle. The action, in turn, is set in an apparent paradisiacal country; the excessive delight for the ruins of ancient cities in chapter III; the contrast between the characters (Ana's illness and Adela's vitality, the candid Sol before Lucia's complexity or the frivolity of Pedro Real before Juan Jerez's deep social commitment): they are all genuinely romantic features.

If, on the one hand, the change of title that Martí thought for his novel could be related to ways of proceeding typical of the Latin American literature of the moment, other marks of his discourse, however, distance it from it. His status as raigal poet generates the discourse of the novel to be a prose of high poetic quality evident, both in the language of the characters and the voice of the narrator. His interest in highlighting beauty is remarkable, not only in the characterization of the characters, but also in the environments where the dramatic action takes place, both in the interior and in the natural spaces. That is a feature that characterizes the modernist narrative.

The meticulous description of the costumes of the female characters, their hats and the particularities of their chocolate cups related to each temperament constitute an expression of elegance and refined taste, and are closely related to fashion in the United States at that time. If we compare the samples of the Fashion Supplement that accompanied each edition of the newspaper El Latino-Americano, similarities will be found with the descriptions of the narrator. The recent fashions that surrounded the author in the streets perhaps could be source for the meticulous description of the narrator.

It also happens with the characterization of spaces. The house where the dramatic action happens is not a common house. Each object that is described as part of the decoration is unique, exquisite: 
books on the mantelpiece are essential pieces of universal literature (El Cuervo, by Edgar Allan Poe; Las Noches by Alfredo Musset; or Rubayat, the Persian poem; the paintings of the living room are of notable painters (Madrazo, Nittis, Fortuny), the courtyard of the house is full of magnolias that are characterized by the white color of its petals, some characters talk about the fashions of Paris and Belgium, others attend the operatic version of Rigoletto, there is a marked interest in showing the taste for novelty and an environment of cultural, social and political modernization of an environment, which is typical of the modernist narrative.

The dialogue that establishes the discourse of the novel with painting, sculpture, music and literature, exalts it. It is not by chance that several of the characters are creators: a painter (Ana), a successful musician (Keleffy) and a poet (Juan Jerez); from his characterization and his dialogues, the topics of art come to the narrative. Even, on several occasions, the narrator reflects on the functions of art:

It improves and relieves the constant contact of the beautiful. Everything on earth, in these black times, tends to lower the soul, everything, books and paintings, business and affections, even in our blue countries! It is always good to have in front of the eyes, around, adorning the walls, animating the corners where the shadow takes refuge, beautiful objects that color and dissipate it. (OCEC: 2011, v. 22, p. 245)

The discourse of the novel appropriates the expressive instruments that these arts offer, a characteristic that distinguishes the modernist narrative. All this appears imbricated in the text presaging subtly the destiny of the characters. The presence of the pianist Keleffy creates correspondences between his music and painting. With his notes on the piano: "in the clouds of light colors were drawn as garlands of wild flowers" (p. 270) or through the images that are sketched in Ana's canvases dramatic conflicts are expressed. In the novel there is a dialogue of symbols interwoven by the correspondence between different artistic expressions. An edge that is also evident in the discourse of Martian chronicles. Another debt of journalism, specifically the modernist chronicle.

Also, in the character system, the male protagonist is not a simple lover of love. $\mathrm{He}$ is a poet; he is an intellectual who has a social project defined in terms of defending the land rights of the original inhabitants. His characterization is singular: "He was of the select race of those who do not work for success, but against it". He is the ethical hero of the novel because of his integrity, his conduct, his personality. Criticism has 
defined him as a modern intellectual with an anti-colonial project.

The "horizon of expectations" around the only novel by José Martí has undergone substantial changes since 1953 until the studies that appeared in 2013. After several decades of silence, the Argentine essayist Enrique Anderson Imbert presents his study at the Congress of Martian Writers -held in February 1953 in Havana, on the occasion of the centenary of the birth of José Martí.

The Cuban essayist Margarita Mateo Palmer states that:

A first approach to the Martian novel, due to the romantic characteristics of the subject recreated by Martí and the presence of some typical expressions of the sensitivity of the 19th century, distance the Martian novel from the current sensibility and seem to place it in a field similar to that of the novels read in the text itself. However, a closer reading of the narrative keys offered by the work, allows to locate it at the beginning of that change of sign towards a new narrative that will reach an extraordinary force in the 20th century, and also, in a more renovating plane than the novels that are favorite reading of the own characters created by Martí. (2015, p. 159)
The degree of experimentation and expressive freedom that the chronicle as a genre allowed José Martí slipped at the time of the writing of his novel and, perhaps, this could explain the heterogeneous nature of the discourse of each of its chapters or the interspersed nature of the own novelistic discourse that alternates the narrative with long reflective sections of the narrator on issues that concern him about the context, similar to those addressed in his journalistic chronicles, but which interfere with the flow of the story. The nov$\mathrm{el}$ is a space of generic confluence. This makes it an atypical text for its time and, perhaps, one of the reasons that, apparently, continues to disrupt readers. Its nature at times approaches not only the essay, but also the drama; at times, the chronicle; or, suddenly, the narrator himself quotes the opinion of a chronicler, published that day in a diary. In turn, from the voice of the characters, the dialogue is permeated by the news style when commenting on these events or from the ruling voice in the speech the journalistic tone is transparent, perhaps to provide contextual elements to the reader. See "Amistad funesta: dialogo intertextual”, by Marlene Vázquez Pérez (2000), where these correspondences are addressed in greater depth.

The irregularities of his discourse (that is to say, those three chapters conformed in a different way and discursive disparity nature, with a certain internal frag- 
mentation and a fluidity of the dramatic action that is not homogeneous) perhaps also respond to that peculiar fragmentation of the modernist chronicle pointed by Susana Rotker (1991) and that will be something proper of the novel that arises later on the continent. It is a novel of the nineteenth century with a disquieting discourse and structure for the critique of each period since its publication with the author's name.

\section{Bibliographic References}

Arencibia, L. (2000). El traductor Martí. Pinar del Río: Ediciones Hermanos Loynaz.

Centro de Estudios Martianos. Obras Completas Edición Crítica. La Habana.

Centro de Estudios Martianos. Obras Completas. La Habana.

Esteban. A. (1995). "Prólogo”, en José Martí: Cuentos completos: La Edad de Oro y otros relatos. Barcelona : Instituto de Cultura "Juan Gil-Albert" y Anthropos.

Hidalgo Paz, I. (2012). José Martí. Cronología (1853-1895). La Habana: Centro de Estudios Martianos.

Martí, J. (1991). "Puertos y porteños", en Obras completas, t. 14, edit. Ciencias Sociales, pp. 293-296.

(1991). "Cataluña contra España”, en Obras completas, t. 14, edit. Ciencias Sociales, 1991, pp. 473-477
Martí, J. (1981). Hora de lluvia. Anuario del Centro de Estudios Martianos, no. 4, La Habana, p. 8

Mateo Palmer, M. (2015). "De una novela sin arte: Lucía Jerez y la narrativa moderna en Hispanoamérica”, en Anuario del Centro de Estudios Martianos, no. 38, La Habana.

Nuñez, M. . (2003). El espacio americano en la novela de José Martí, en Anuario del Centro de Estudios Martianos, no. 25. La Habana:, pp. 168-176.

(2014). Martí. Narrar desde el periodismo. Colección Patria. La Habana: Editorial Martí.

Rotker, S. (1991). Fundación de una escritura: las crónicas de José Martí. La Habana: Casa de las Américas.

Suárez León, C. (2002). "Martí: traductor de textos, traductor de mundos", en Anuario del Centro de Estudios Martianos, no. 25, La Habana, p. 178

Vázquez Pérez, M. (2000). "Amistad funesta: diálogo intextextual" en Anuario del Centro de Estudios Martianos, no. 23. La Habana: Centro de Estudios Martianos, pp. $46-53$ 